\title{
WZB
}

Wissenschaftszentrum Berlin

für Soxialforschung

Nicolas Grießhaber

Benny Geys

Civic Engagement and Corruption in 20 European Democracies

Discussion Paper

SP II 2011-103

September 2011

Social Science Research Center Berlin (WZB)

Research Area

Markets and Politics

Research Professorship \& Project

The Future of Fiscal Federalism 
Wissenschaftszentrum Berlin für Sozialforschung gGmbH

Reichpietschufer 50

10785 Berlin

Germany

www.wzb.eu

Copyright remains with the author(s).

Discussion papers of the WZB serve to disseminate the research results of work in progress prior to publication to encourage the exchange of ideas and academic debate. Inclusion of a paper in the discussion paper series does not constitute publication and should not limit publication in any other venue. The discussion papers published by the WZB represent the views of the respective author(s) and not of the institute as a whole.

Affiliation of the authors other than WZB:

\section{Nicolas Grießhaber}

Berlin Graduate School of Social Sciences (BGSS)

BGSS, Unter den Linden 6, 10099 Berlin, Germany

\section{Benny Geys}

WZB and Norwegian Business School (BI)

Norwegian Business School (BI), Nydalsveien 37, 0442 Oslo, Norway 
Abstract

\title{
Civic Engagement and Corruption in 20 European Democracies
}

\author{
Nicolas Grießhaber and Benny Geys
}

This paper analyzes the relation between different forms of civic engagement and corruption. This first of all extends earlier analysis linking generalized trust to corruption by incorporating another element from the social capital complex (namely formal forms of civic engagement). Second, based on the idea that social networks' beneficial or harmful impact may depend on their characteristics, it investigates how the structure of social networks (i.e., inclusive vs. exclusive and isolated vs. connected) matters. Evaluating the engagement - corruption nexus for a cross-section of 20 European democracies in $2002 / 2003$, we confirm that social networks are linked to corruption even when controlling for the effect of generalized trust, and that their relation to corruption is typespecific. These findings survive under various model specifications and robustness checks.

Keywords: Corruption, civil society, networks, voluntary associations, European social survey 


\section{INTRODUCTION}

Although some scholars emphasize potential beneficial impacts of corruption - most often understood as the 'misuse of public office for private gain' (e.g., Bardhan 1997, p. 1321; Treisman 2000, p. 399) - on bureaucratic efficiency and economic development (e.g., Leff 1964; Klitgaard 1988; for empirical support, see Egger and Winner 2005; Méon and Weill 2010; Dreher and Gassebner 2011), corruption today is widely believed to be inimical to selfsustaining growth and development (e.g., Tanzi 1998; Jain 2001). Consequently, there developed a significant body of academic work that analyzes the determinants of corruption in order to uncover elements that might facilitate it, or assist its prevention (for reviews, see Svensson 2005, Seldadyo and De Haan 2006; Treisman 2007).

A recent strand in this research tradition addresses the potential relation between social capital (i.e., 'features of social organization, such as trust, norms, and networks'; Putnam 1993, p. 167) and corruption (e.g., La Porta et al. 1997; Bjørnskov 2003; Uslaner 2004; Delhey and Newton 2005; Lambsdorff 2007). The present paper adds to this literature in three main ways.

- First, research to date concentrates almost exclusively on the effect of trust as a component of social capital, arguing that 'higher levels of honesty and trust that others will conform to a given set of norms' lead to lower corruption (Bjørnskov 2003, p. 3; see also La Porta et al. 1997; Uslaner 2004; Delhey and Newton 2005; for an alternative view, see Lambsdorff 2007). Yet, as mentioned, the social capital concept is broader than trust (Putnam 1993; Coffé and Geys 2005; Sabatini 2009). Hence, concentrating only on the effect of trust gives, at best, a partial view of the social capital-corruption relation. Explicitly acknowledging social capital as a multidimensional concept, this study incorporates formal networks of civic engagement into the analysis. By evaluating a different aspect of the social capital complex (while controlling for trust), this allows generating a more complete view of the link between corruption and social capital. $^{1}$

- Second, while most social capital scholars stress trust's positive consequences (see above), this effect might well be particular to generalized rather than particularized trust (Warren 2004). ${ }^{2}$ Indeed, Harris (2007) reveals that indicators of strong ties, family orientations and particularized trust are associated with significantly higher corruption. Similarly, while social capital theory generally emphasizes the beneficial role of social networks for society (e.g., Putnam 1993; see, however, critical discussions in Levi 1996; Foley and Edwards 1998; Zmerli, 2010) - thus predicting lower corruption with increasing civic engagement - research on interest-group politics (e.g., Olson, 1965, 1982; Grossman and Helpman 2001) generates the reverse prediction. Our analysis adds to the literature by explicitly evaluating these potential 'dark shades' of social capital (van Deth 2010, p. 640; see also Iglič 2010; Zmerli 2010).

- Finally, as the relative importance of the positive and negative effects indicated above might depend on networks' constituting features, we analyze to what extent the relation

1 While O'Connell (2003, p. 243) employs the 'average number of organizational memberships per person' as a measure of social capital and connects this to 'the perception of corruption in each society', his work does not simultaneously control for the effect of trust - as we do - nor does he assess the potentially different roles played by various types of associations (see below).

2 Unlike particularized trust, which is based on personal knowledge and, hence, restricted to a specific social unit (Freitag et al. 2009), generalized trust can be defined as an 'estimate of the probability of trustworthiness, $\mathrm{p}^{*}$, for the average person' (Coleman 1990, p. 104). It is therefore independent of specific persons or groups, and based on the assumption that most people are part of the own 'moral community' (Uslaner 2003). 
between formal networks of civic engagement and corruption depends on these networks' characteristics. The central differentiation - defined in more detail below - is thereby based on their constitutive purposes (inclusive vs. exclusive associations; Warren 2001, 2004; Zmerli 2003) as well as their connectedness to other networks (isolated vs. connected associations; Paxton 2002, 2007). This allows analyzing recent arguments stating that social networks based on exclusiveness and social isolation may promote opportunism, strong in-group cohesion and favouritism instead of civic virtues (e.g., Paxton 1999, 2002, 2007; Putnam 2000). ${ }^{3}$

Using a sample of 20 European democracies and employing the Corruption Perceptions Index of Transparency International as the central dependent variable our results show that the density of social networks in a society adds to the explanatory power of the model even when controlling for the effect of generalized trust. This provides strong evidence that civil society matters beyond breeding social trust. Moreover, the relation between social networks and corruption depends on their type: inclusive organizations are associated with lower corruption and exclusive organizations with higher corruption. Overall, our results thus provide evidence that, although civic engagement on the whole is connected to lower corruption, high levels of certain types of civic engagement are actually linked to higher, rather than lower, corruption.

The remainder of the paper is organized as follows. Section 2 introduces the concept of social capital, emphasizes the role of social networks as a structural component thereof, and outlines our main hypotheses. Section 3 introduces the empirical methodology, while our results are discussed in section 4 . The last section concludes.

\section{NETWORKS OF VOLUNTARY CIVIC ENGAGEMENT AND CORRUPTION}

Over the last 20 years, 'social capital' has been linked - in an exploding body of research - to numerous positive societal, economic and political outcomes including lower crime rates (e.g., Messner et al. 2004), improved economic development (e.g., Knack and Keefer 1997) as well as the rise and persistence of democracies and the performance of governments (Putnam 1993; Paxton 2002; Coffé and Geys 2005; Tavits 2006). Social capital is thereby most often understood to refer to 'social networks and the norms of reciprocity and trustworthiness that arise from them' (Putnam 2000, p. 19), and thus complements physical capital, which refers to material objects, and human capital, which is embodied in personal qualities and skills of individuals. For most scholars, social capital therefore entails a combination of structural and cultural elements (Hooghe and Stolle 2003; Coffé and Geys 2005, 2006; Sabatini 2009; van Deth 2010). The latter incorporate aspects of interpersonal trust, social values and norms of reciprocity. The structural component refers to social networks and interpersonal relations, either formal or informal (Pichler and Wallace 2007).

Unlike previous corruption work (see above), this study focuses on the latter pillar of social capital, measured as 'social connectedness through associational life' (Freitag 2006, p. 124), while controlling for potential effects of the former (i.e., trust). According to social capital

Some recent studies have similarly addressed potential differences between the effects of various types of social networks (i.e., friends, family, voluntary organizations) on economic development and growth (e.g., Beugelsdijk and Smulders 2003; Sabatini 2009). However, such studies often implicitly presuppose that all voluntary associations have the same effect. Yet, in reality, there is likely to be significant variability across such associations (e.g., Knack and Keefer 1997; Paxton 1999; Zmerli 2003; Coffé and Geys, 2007; van Deth 2010). Using recently-developed methodological tools, this variability will be explicitly taken into account and exploited in our analysis (see below). 
scholars, social networks can affect corruption via two mechanisms. First, networks of civic engagement have been argued to promote development of norms of reciprocity and social values (Putnam 1993), which can easily spill over beyond the immediate group (e.g., Newton 2006). By thus promoting democratic skills and attitudes, formal social networks negatively affect the occurrence of corruption. Second, social networks' structures allow people to become part of the political process (Putnam 1993; Boix and Posner 1998; Jottier and Heyndels, 2011). They increase political awareness (e.g., Scheufele et al. 2004) as well as voters' ability to 'more easily overcome the collective action problem in monitoring officials' (Knack 2002, p. 273; Jottier and Heyndels, 2011). This implies that, in a society with a dense network of civic engagement, the probability to detect illicit rent extraction is higher, which, as a result, decreases corruption (cf. Shleifer and Vishny 1993). In both cases, a flourishing associational life creates an environment unfavourable to the development of widespread corruption.

\section{H1a: Societies with high civic engagement experience a lower level of corruption.}

Yet, social networks might not only teach civic skills, social responsibility and cooperation. Strong group ties might also be bad for society (Coleman 1988; Portes 1998; Foley and Edwards 1998). The Weimar Republic in Germany, for instance, had a very vibrant civic life, but its organization of associations along existing social cleavages has been argued to reinforce rather than defeat narrow, group-specific interests (Berman 1997). Similarly, Olson (1982) argues that specialized interest groups have a stronger incentive to engage in costly and inefficient rent-seeking than to work toward the 'common good'. This idea has subsequently become central to a large political economics literature on special interest groups (e.g., Grossman and Helpman 2001). Its line of argument implies a hypothesis directly opposite to $\mathrm{H1a}$; namely, that civic engagement might increase corruptive practices.

\section{H1b: Societies with high civic engagement experience a higher level of corruption.}

Because social networks differ with respect to their characteristics, purposes and members, it is conceivable that the (positive or negative) effect of a given social network depends on its design. To evaluate this, we regard two differentiations recently proposed in the literature: i.e., based on networks' constitutive purposes (inclusive vs. exclusive associations; Knack and Keefer 1997; Zmerli 2003) or their connectedness to other networks (isolated vs. connected associations; Paxton 2002, 2007).

The distinction between exclusive and inclusive social capital captures the difference between networks or organizations that are based on a strong in-group/out-group distinction and inward-orientation (i.e., focused predominantly on members' personal interests), and those with a broader, societal focus that reach across the boundaries of the organization (Knack and Keefer 1997; Zmerli 2003). ${ }^{4}$ The idea - in part inspired by the distinction between strong and weak ties put forward by Granovetter (1973) - is that the former networks enforce exclusive group identities and build strong in-group cohesion, but are less integrated into the broader community and thereby contain the risk of negative externalities and strong out-group antagonisms (Zmerli 2003, Freitag et al. 2009, van Deth and Zmerli 2010). Strong in-group orientation and specific reciprocity may indeed lead members to develop feelings of obligation to favour and support people from the same group, which may support corruptive practices (Harris 2007). Fukuyama (2000, p. 8) even sees this as a 'cultural foundation for

According to these same authors, human rights and environmental organizations are typical examples of inclusive networks, while professional interest groups, social clubs and student fraternities are key examples of exclusive groups (more details below). 
corruption'. Societies can thus 'be rich in social capital within social groups, and yet experience debilitating poverty, corruption and conflict' (Narayan 1999, p. 8, italics added). Inclusive networks, on the other hand, strive for collective goods and therefore possess an outward orientation (Zmerli 2003, van Deth and Zmerli 2010), making them more likely to generate civic virtues, 'broader identities and reciprocity' (Putnam 2000, p. 22n; Freitag et al. 2009, Zmerli 2010). Hence, inclusive associations should be more likely to generate publicspiritedness and interest in the common good, which have been argued to reduce corruption. This line of argument leads to the following hypotheses:

H2: $\quad$ The level of corruption decreases with the density of inclusive social networks.

H3: $\quad$ The level of corruption increases with the density of exclusive social networks.

While the distinction between inclusive and exclusive networks emphasizes the structure within individual organizations, the differentiation between connected and isolated networks (Paxton 2002, 2007) focuses on the structure between associations. Social networks thereby count as well-connected when they 'are linked to other voluntary associations through the multiple memberships of their members' (Paxton 2007, p. 51). Such multiple affiliations 'generate organizational embeddedness' (Cornwell and Harrison 2004, p. 863), which facilitates the development of between-group trust because members know at least some people in other groups and parts of society. Reversely, isolated networks can be expected to mainly develop strong internal ties, social closure and in-group cohesion (Granovetter 1973). This, as mentioned, reduces their incentive to work towards the common good, and might motivate the pursuit of narrow group interests. This leads to the following hypothesis:

H4: A high density of connected social networks is linked to less corruption, while a high density of isolated social networks is linked to higher corruption.

Before we turn to the empirical analysis, it is important to point out that our hypotheses suggest that causality runs from involvement in social networks to corruption. Although some existing theoretical and empirical research supports this by pointing towards a causal effect of trust on corruption (Putnam 1993; Bjørnskov 2003; Uslaner 2004), the question of causality remains open (e.g., the reverse direction of causation is supported by You 2006; Rothstein 2006; Lambsdorff 2007). Indeed, higher corruption might lead people to place less trust in political institutions (e.g., Morris and Klesner 2010) and, as a consequence, to rely more heavily on themselves or closely-knit personal networks rather than, say, societyoriented groups. We return to this discussion below.

\section{DATA AND METHOD}

To evaluate the relation between engagement in social networks and corruption, we estimate using OLS - the following estimation equation (with subscript i for country):

$$
\mathrm{CPI}_{\mathrm{i}}=\mathrm{a}+\mathrm{b}_{1} \text { Networks }_{\mathrm{i}}+\mathrm{b}_{2} \text { Controls }_{\mathrm{i}}+\mathrm{e}_{\mathrm{i}}
$$

We test this model using a sample of 20 European democracies. While corruption data are more widely available, our sample size is restricted because data on social networks are extracted from the 2002/2003 round of the European Social Survey (ESS). Hence, only countries participating in this round could be included (more details in section III.2). Even 
though other surveys such as the World Values Survey (WVS) would offer a broader sample, we prefer to use the ESS because it provides detailed information on civic engagement in voluntary associations and its methodology is robust across participating countries. ${ }^{5}$

\section{III.1. Dependent variable}

The dependent variable is Transparency International's Corruption Perceptions Index (CPI) for the year 2003. Although there are other measures of corruption perceptions (e.g., World Bank's Control of Corruption Index, International Country Risk Guide), these are generally extremely highly correlated with each other. We rely on CPI as it is probably 'the most widely known corruption indicator' (Knack and Azfar 2003, p. 6) and a standard choice in the literature (e.g., O'Connell, 2003). CPI is a composite index, aggregating different polls of business people and assessments by country analysts on perceived corruption at the country level. These data are standardized using non-parametric statistics ensuring the index to range from 0 (highly corrupt) to 10 (highly clean). The resulting index is presented in Figure 1. It shows that corruption perceptions are lowest in the Scandinavian countries (with Finland ranked first among all countries for which the index is computed). The highest corruption perceptions in our sample are observed for the Eastern and Southern European countries.

[Figure 1 around here]

Clearly, as the CPI is based on subjective perceptions rather than real corruption, it bears the risk of bias due to rumours, prejudice, country stereotypes, media attention, previous corruption ratings or macro factors like a country's economic performance (Lambsdorff 2003; Søreide 2003). While acknowledging their potential influence, more direct measures of corruption - such as convictions for corruption - are unable to capture undetected corruption and often end up measuring other aspects such as the quality of law enforcement (Ades and Di Tella 1997). Moreover, as it is impossible to have anything near perfect information about the extent of corruption, people in the end have to act on their perceptions. Hence, we prefer to nonetheless rely on the CPI, which also makes our results more directly comparable to those of O'Connell (2003).

We should also note that an ideal sample to examine how the structure of civil society impacts upon corruption would include developing and transition countries. Given our reliance upon ESS data, such countries could unfortunately not be included in the present analysis. Nonetheless, the limited variation in our dependent variable that derives from using 20 European countries also has a bright side as it increases the difficulty to find significant relations. Hence, our sample can be seen a least-likely case for uncovering structural effects, making it a strong test of the hypotheses derived above.

\section{III.2. Main independent variables}

Networks $_{\mathrm{i}}$ is a vector incorporating information about involvement in formal social networks in country $i$. This is measured using information on participation in and voluntary work for voluntary associations and is extracted from the European Social Survey (ESS). For each of 12 association types (Sports/outdoor activity, culture/hobby, trade union, professional, consumer, Humanitarian/human rights, Environment/peace/animal rights, Religious, Political,

\footnotetext{
The ESS is a biennial survey with minimum effective sample size of 1,500 respondents for each country ( 800 for countries with a population below 2 million). The first round (2002/2003) was carried out in 22 European countries and contained a special focus on civic engagement. Note that the civic engagement questions were not included in Switzerland and the Czech Republic, such that these countries are excluded.
} 
Education/teachers/parents, Social club, other), respondents are asked whether they were a member, have participated, donated money or did voluntary work over the preceding 12 months. To most closely capture the idea that respondents are actively involved in a formal, institutionalized social network, we focus on participation and voluntary work instead of mere membership. Importantly, the exact content of this 'Networks' vector differs across the various models we analyze. Indeed, when evaluating $\mathrm{H} 1 \mathrm{a}$ and $\mathrm{H} 1 \mathrm{~b}$, we include the percentage of respondents in country $i$ that acknowledge active participation or voluntary work in at least one type of association. For hypotheses 2 through 4, we separate this information in two different categorizations.

First, to distinguish inclusive from exclusive networks, we follow Zmerli (2003) by identifying the basic purpose - or 'constitutive goods' (Warren 2001) - of each association type. ${ }^{6}$ We thereby distinguish six 'constitutive goods': individual material goods, status goods, group identity goods, public material goods, inclusive social goods and interpersonal identity goods (Warren 2001; Zmerli 2003). As the main foundation and central inspiration for the ideals and aims of a voluntary association, these constitutive goods should have a significant impact on determining the character of the organization. The idea underlying the inclusive/exclusive networks distinction then is that groups focusing on individual-oriented goods such as personal material, status or group identity goods are more likely to generate exclusiveness (Zmerli 2003; van Deth and Zmerli 2010). Pursuing personal material interests (or 'individual material goods') does not necessarily require collective action and even when it does its aim lies in narrow self-interest. As such, the pursuit of such goods is unlikely to help foster inclusive networks that espouse civic virtues. Examples of voluntary associations pursuing such aims include farmers unions and business lobbies (Zmerli 2003), which mainly aim at improving the material situation of a (very) limited, well-defined section of society. Instead of material interests, 'status goods' refer to symbolic values that are excludable - such as social status, degrees or titles. A central focus on such status goods likewise generates exclusiveness, since solidarity and empathy are more likely to be restricted to those who share the same status. An example concerns social clubs or certain professional organizations, where the in-group defines itself through some characteristic that is, by definition, absent in the out-group. Similar reasoning applies to groups that are defined by specific characteristics of its members such as gender, age, ethnicity or language ('group identity goods'; e.g., women or youth organizations). In both cases, exclusive identities and strong in-group cohesion are likely to be enforced and groups having such goods as their basic purpose are more likely to generate exclusive social capital.

On the other hand, groups that pursue 'public material goods' which are scarce, nonexcludable and beneficial for the wider society are likely to enhance civic values, social responsibility and an outward-orientation. The reason is that they remind their members of individual interdependencies and the need for collective action (e.g., environmental groups; Zmerli 2003). In addition, organizations that are devoted to preserving common resources and values such as language, culture, societal ideals and identities ('inclusive social goods'; e.g., human rights associations and cultural groups) as well as associations based on strong interpersonal relations ('interpersonal identity') that teach their members empathy and trust (e.g., sports and hobby clubs, parents associations) are also assumed to enhance civic values, social responsibility, outward-orientation and an inclusive character (Zmerli 2003). This discussion leads to the designation of trade unions, professional associations, consumer and social clubs, youth, elderly and women's organizations as predominantly exclusive. Sports, hobby, humanitarian, environmental, animal rights, parent/teacher associations as well as

6 Evidently, we exclude the 'other' category in making this distinction (and similarly below). 
church groups and political parties are designated as predominantly inclusive (see Table 1 below, based on Zmerli 2003). The final network-variables measure the percentage of respondents in country $i$ that state active participation or voluntary work in at least one association defined as inclusive and exclusive, respectively.

We should note here that, though we chose to follow the allocation made in earlier work (especially Zmerli, 2003) for reasons of comparability, these allocations may not be without criticism. For instance, one might argue that church groups are mainly based on exclusive group identities (i.e., religious denomination). However, in most cases, such groups arguably aim at enhancing broader identities and solidarity which go beyond the mere members of the group, giving such networks a more inclusive character (see Zmerli, 2003). Similarly, political parties might be argued to pursue the interests of their clientele. Nevertheless, a more benevolent (and possibly naïve, but certainly less cynical) view of politics starts from the perspective that politicians represent the population and are concerned with the provision of public goods to the benefit of society. ${ }^{7}$

\section{[Table 1 around here]}

Second, to differentiate connected and isolated organizations, we follow Paxton $(2002,2007)$ and Freitag et al. (2009) in calculating the average number of additional association types in which active participants of a given group are likewise involved. Unlike these authors, however, we correct this number for the relative size of each association type in each country. Not doing so 'would unduly benefit (punish) small (large) groups since all [participants] of a small group can also be [participants] of a large group, but not the other way round' (Geys and Murdoch 2010, p. 4). The reason is that, since links between associations are necessarily symmetric, 'the size of the groups distinguished by a given parameter is inversely related to the extent of their intergroup relations' (Blau 1977, p. 24). ${ }^{8}$ Once again following Paxton (2002, 2007), we then designate the three association types with the lowest level of (corrected) interconnections as isolated, and all others as connected (note that the exact delineation of association types across this typology thereby differs across countries; details provided in Table A2 in Appendix A). ${ }^{9}$ The final network-variables in this case equal the percentage of respondents in country $i$ that state active participation or voluntary work in at least one association defined as isolated or connected, respectively.

\section{III.3. Control variables}

Clearly, as we have a maximum of 20 countries, only a limited number of control variables can be included simultaneously in the estimations to avoid running out of degrees of freedom. While we experimented with an extensive battery of control variables (see also below), our baseline model always includes GDP per capita (measured in 2000 to mitigate concerns of endogeneity bias and taken from the OECD Factbook). Inclusion of this variable appears a

\footnotetext{
With respect to religious groups, we also ran all regressions below excluding religious organizations - as suggested by Putnam (1993). This leaves our results qualitatively unaffected.

8 This correction involves a simple OLS regression where the average number of participations of individuals participating in a given association type in country $\mathrm{i}$ is the dependent variable and the total number of participants of these same association types in a given country the explanatory variable. Higher (lower) residuals from this regression indicate associations having more (less) interconnections than its participantbase would suggest, implying higher (lower) connectedness net of the participant-size effect (see also Coffé and Geys 2008; Geys and Murdoch 2008).

9 While this follows Paxton $(2002,2007)$, selection of just three associations as isolated is obviously ad hoc. Still, re-estimating the model taking four associations as isolated, makes no difference to the results (available upon request).
} 
basic requirement as earlier work has consistently shown it to be a core determinant of corruption (Seldadyo and De Haan 2006; Treisman 2007). Further, we also always introduce the level of generalized trust in a society. This variable is important for our analysis as this main cultural component of social capital not only controls for the potential direct impact of trust (as identified by, e.g., Bjørnskov 2003; Uslaner 2004), but also evaluates the indirect effect of social networks via their impact on interpersonal trust (or, reversely, how such trust affects membership; see Sønderskov 2011). ${ }^{10}$ Summary statistics and definitions for these variables are provided in Appendix A.

As mentioned, in order to mitigate potential omitted variable bias, we experimented with a large number of alternative specifications and variables that were identified in the literature as potential influences on a country's level of perceived corruption (e.g., Mauro 1995; Ades and di Tella 1999; La Porta et al 1999; Fisman and Gatti 2002; Paldam 2002; Gerring and Thacker 2005; You and Khagram 2005): e.g., income inequality, ethno-linguistic fractionalization, trade as a share of GDP, ratio of children enrolled for secondary education, World Bank Governance Indicators (i.e., government effectiveness and regulatory quality, see Kaufmann et al. 2003), decentralization, legal tradition, percentage of respondents belonging to specific religious denominations, north/south dummies, and so on. None of these variables' inclusion (or exclusion) affected the qualitative interpretation of the main findings for the baseline model reported below and we therefore, for reasons of parsimony, confined our main empirical model to the core variables described above (details available upon request).

\section{EMPIRICAL FINDINGS}

Table 2 reports our main results. In models (1) and (2), we examine the relationship between corruption and voluntary associations in general, such as to address H1a and H1b. In model (2), we thereby control for the level of generalized trust, while in model (1) we do not - such as to evaluate the indirect effect of trust through associations. In the remaining columns, we distinguish between inclusive and exclusive (model (3)) as well as between connected and isolated (model (4)) social networks. Finally, in model (5), we introduce both differentiations at the same time to check the extent to which they are measuring similar effects (Geys and Murdoch 2008, 2010).

\section{[Table 2 around here]}

Table 2 first of all indicates that, as in the preceding literature, GDP per capita acts as a central economic determinant of corruption perceptions, also within the current sample of European countries (see Paldam 2002; Treisman 2007). Generalized trust is, in line with previous findings, likewise found to be very important and generates a noted increase in the explanatory power of the model: i.e., trusting societies show lower levels of perceived corruption (see also La Porta et al. 1997; Bjørnskov 2003; Uslaner 2004; Delhey and Newton 2005).

10 Generalized trust is measured using respondents' answers to: 'Generally speaking, would you say that most people can be trusted, or that you can't be too careful in dealing with people?' We use the average score for each country, which lies on a scale from 0 ('you can't be too careful') to 10 ('most people can be trusted'). Although the credibility of this measure depends on what respondents understand under 'most people' (i.e., the so-called 'radius of trust' problem), recent research has shown that the "question seems to work well in Western and affluent nations" (Delhey et al., 2011: 25), which are the focus of the current analysis. 
Turning to our central variables, we first of all find that active involvement in voluntary associations is consistently positively correlated to the perception of a countries' level of corruption (remember that higher numbers on CPI indicate lower corruption perceptions, such that civic engagement links to lower corruption). This effect remains even after controlling for important background variables such as generalized trust and GDP. Specifically, we observe that the coefficient estimate and significance level both decrease significantly with the inclusion of generalized trust in model (2), which suggests that at least part of associational involvement's correlation runs indirectly through social trust. However, given that introducing generalized trust does not eliminate the significance of the civic engagement variables, our findings strongly suggest that civil society matters beyond breeding social trust. These results thus provide significant support for H1a rather than H1b. In general, societies with high active involvement in civic engagement are characterized by a lower level of corruption (even in our sample of developed European countries). Still, the observed association remains relatively modest as a one standard deviation change in involvement relates to a change in corruption perceptions equal to roughly one third of its standard deviation (evaluated at the mean value). One possible reason for this modest effect, as argued in section 2, might be that there are opposing effects from different association types.

This argument is substantiated in the remainder of Table 2. Indeed, in line with $\mathrm{H} 2$ and $\mathrm{H} 3$, the share of inhabitants actively involved in inclusive, outward-oriented formal social networks goes hand in hand with lower levels of corruption, while participation or voluntary work for social networks characterized by exclusive group identities and an inwardorientation are linked with higher levels of corruption (see model (3)). Even after controlling for trust and GDP, this difference in the coefficient estimates of inclusive and exclusive networks is statistically highly significant (as shown at the bottom of Table 2). Moreover, there is a further sizable increase in the explanatory power of the model (from $87.7 \%$ of variance explained in model (2) to $91.1 \%$ explained in model (3)). This indicates that differentiating both types of networks provides a better explanation for cross-country variation in corruption perceptions than taking all associations as a common factor. A similar differentiated effect cannot, however, be observed for isolated versus connected social networks (see model (4)). As such, we cannot substantiate H4. The distinction between inclusive and exclusive networks therefore appears to be the more important one. ${ }^{11}$ Note, finally, that including measures for both differentiations (see model (5)) leads to insignificance of all network variables due to severe multicollinearity problems (correlations between these measures lie above 0.80, while their Variance Inflation Factors are consistently well above the commonly proposed threshold value of 20 ).

As mentioned above, these basic results are robust to the inclusion of any of the additional control variables listed at the end of section III.3 - severely mitigating any concern that our results are driven by the exclusion of important control variables. They are also robust to using alternative specifications for the dependent variable. Indeed, similar results are obtained when using the average CPI over the 2002-2004 period, the CPI index for 2010 as well as the average CPI over the period 2008-2010. While the former intends to mitigate the potential effect of measurement error in the annual data, the latter two specifications provide a partial attempt to weaken concerns about reverse causality (as current corruption perceptions cannot

11 Note that all models were tested for influential cases using Cook's D as test statistic. Exclusion of such cases leaves our results qualitatively unaffected (details available upon request). If anything, removing any outliers tends to slightly improve our results. 
logically affect involvement in 2002/2003). ${ }^{12}$ In this respect, it is important to observe that the year-on-year CPI data generally show a correlation in excess of 0.985 in our sample, but that such correlation is somewhat less extreme when comparing the data for 2003 and 2010 $(\mathrm{r}<0.93)$. Although the explanatory power of models using more recent CPI data is, as might be expected, significantly lower (with $\mathrm{R}^{2}$ around $82 \%$ to $85 \%$ ), this reduction is mainly due to the weaker explanatory power of GDP in such models. The core findings with respect to association memberships remain robust. Finally, it is important to note that Table 2 only regards active participation or voluntary work. Given the controversy in the literature about the benefit of active face-to-face interactions versus passive involvement in formal social networks, we replicated our analysis using measures of civic engagement that are more closely aligned to passive involvement (i.e., dues-paying memberships). As before, we find that the type of civic engagement plays an important intervening role, in line with our main theoretical argument (full results available upon request).

\section{CONCLUDING REMARKS}

This study assessed the relation between formal social networks of civic engagement and corruption perceptions in 20 European democracies. This adds to the literature on the social capital—corruption nexus (e.g., La Porta et al. 1997; Bjørnskov 2003; Uslaner 2004) by introducing the main structural - rather than cultural (i.e., interpersonal trust, social values and norms) - component of social capital. Moreover, we explicitly accounted for the possibility that formal social networks might not merely link to social goods, but to social harms as well.

Our empirical results first of all show that the level of perceived corruption in a country is significantly associated with a society's degree of civic engagement in formal social networks. However, and crucially, not all types of associations share the same positive correlation. Distinguishing between inclusive and exclusive networks - based on the basic purpose of the respective social networks - revealed that only involvement in the former is associated with lower corruption, while involvement in the latter actually shows the reverse tendency. This suggests that public investments supporting civic engagement in general may not have the desired effect on the prevalence of corruptive practices in society (for a similar argument in a different setting, see Grajzl and Murrell 2009).

Even though our results are supportive of theoretical expectations, they also call for further research. First, the sample's restriction to European democracies makes for a strong test (due to the limited variation in corruption), but also limits generalizability of the results. To address this, broader studies including developing countries - where corruption can be a more considerable concern - should be conducted. Secondly, the most recent wave of the ESS (fielded in 2010/11) includes questions about individuals' perceptions of corruption (ESS, 2010). Once these data become publicly available, they will allow for individual- and multilevel analyses of the social capital-corruption nexus, which is likely to provide important new insights. Finally, although social networks' coefficient estimates retain statistical significance after controlling for critical variables such as GDP and trust, these variables are obviously closely related. Future work should investigate more closely the exact relationship between social networks and generalized trust - especially with respect to different types of social networks - to more clearly define the causal pathways in which the associations observed here work.

12 Unfortunately, a more direct approach to address the causality issue using instrumental variable techniques is unfeasible by the lack of viable instruments. This is why we refrain from drawing final causal inferences throughout the paper. 
Figure 1: Perceived Corruption (CPI 2003)

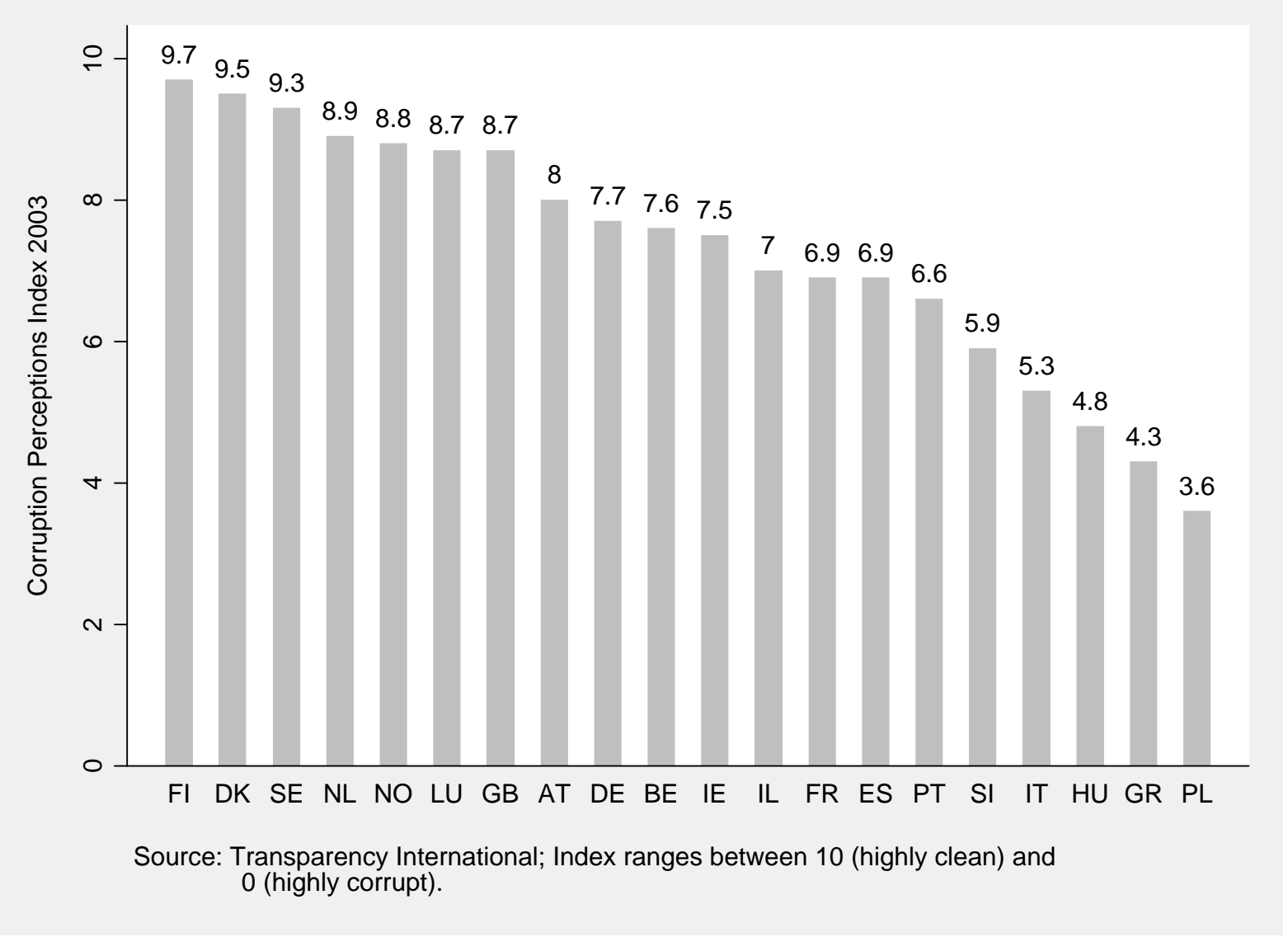


Table 1: Constitutive goods of exclusive and inclusive networks

\begin{tabular}{|c|c|}
\hline Organization & Constitutive Good \\
\hline \multicolumn{2}{|l|}{ Exclusive } \\
\hline Trade Union & Individual Material \\
\hline Business/Professional/ Farmers & Individual Material \\
\hline \multicolumn{2}{|l|}{ Organisation } \\
\hline Consumer/Automobile & Individual Material \\
\hline \multicolumn{2}{|l|}{ Organization } \\
\hline Social Club, Young/Elderly/ & Status Goods/ \\
\hline Women Societies & Exclusive Group Identity \\
\hline \multicolumn{2}{|l|}{ Inclusive } \\
\hline Sport/Outdoor Acivity & Interpersonal Identity \\
\hline Cultural/Hobby Club & Interpersonal Identity/ Inclusive Social \\
\hline Humanitarian Aid/Human & Inclusive Social \\
\hline \multicolumn{2}{|l|}{ Rights/Minorities } \\
\hline Environment/Peace/Animal Rights & Public Material/ Inclusive Social \\
\hline Church/Religious Organization & Interpersonal Identity/ Inclusive Social \\
\hline Political Party & Public Material \\
\hline Science/Education/Teachers/Parents & Interpersonal Identity/ Inclusive Social \\
\hline
\end{tabular}


Table 2: Voluntary Associations and Corruption: Do Association Types Matter?

\begin{tabular}{|c|c|c|c|c|c|}
\hline & (1) & (2) & (3) & (4) & (5) \\
\hline Involvement & $\begin{array}{c}-0.0766 * * \\
(0.0174)\end{array}$ & $\begin{array}{c}-0.0439 * * \\
(0.0164)\end{array}$ & - & - & - \\
\hline Exclusive Associations & - & - & $\begin{array}{c}-0.111 * * \\
(0.0485)\end{array}$ & - & $\begin{array}{c}-0.0618 \\
(0.0948)\end{array}$ \\
\hline Inclusive Associations & - & - & $\begin{array}{c}0.0991 * * \\
(0.0325)\end{array}$ & - & $\begin{array}{c}0.220 \\
(0.220)\end{array}$ \\
\hline Isolated Associations & - & - & - & $\begin{array}{c}0.0321 \\
(0.0584)\end{array}$ & $\begin{array}{l}-0.0288 \\
(0.0996)\end{array}$ \\
\hline Connected Associations & - & - & - & $\begin{array}{c}0.0319 \\
(0.0245)\end{array}$ & $\begin{array}{l}-0.131 \\
(0.222)\end{array}$ \\
\hline Log of GDP per Capita & $\begin{array}{c}1.928 * * * \\
(0.362)\end{array}$ & $\begin{array}{c}1.300 * * \\
(0.462)\end{array}$ & $\begin{array}{c}1.245 * * \\
(0.435)\end{array}$ & $\begin{array}{c}1.350 * * \\
(0.519)\end{array}$ & $\begin{array}{c}1.347 * * \\
(0.505)\end{array}$ \\
\hline Generalized Trust & - & $\begin{array}{c}0.820 * * * \\
(0.237)\end{array}$ & $\begin{array}{c}0.839 * * * \\
(0.176)\end{array}$ & $\begin{array}{c}0.818 * * \\
(0.336)\end{array}$ & $\begin{array}{c}0.826 * * \\
(0.225)\end{array}$ \\
\hline Constant & $\begin{array}{l}-14.97 \\
(3.228) \\
\end{array}$ & $\begin{array}{l}-11.54 \\
(4.135) \\
\end{array}$ & $\begin{array}{c}-10.95 \\
(4.065)\end{array}$ & $\begin{array}{l}-11.83 \\
(4.452) \\
\end{array}$ & $\begin{array}{l}-11.95 \\
(4.677)\end{array}$ \\
\hline Observations & 20 & 20 & 20 & 20 & 20 \\
\hline R-Squared & 0.799 & 0.877 & 0.911 & 0.870 & 0.916 \\
\hline F-Value & $87.89 * * *$ & $34.79 * * *$ & $53.41 * * *$ & $26.13 * * *$ & $30.24 * * *$ \\
\hline Excl=Incl & - & - & $7.20^{* *}$ & - & 3.11 \\
\hline Iso $=$ Conn & - & - & - & 0.00 & 0.52 \\
\hline
\end{tabular}

Note: Heteroscedasticity-corrected standard errors in parentheses; levels of significance: ${ }^{*} \mathrm{p}<0.1,{ }^{* *} \mathrm{p}<0.05, * * * \mathrm{p}<0.01$.

Excl=Incl and Iso=Conn test the significance of the difference in coefficient estimates between both association groups. The test statistic has a $\mathrm{Chi}^{2}$ distribution with one degree of freedom. 


\section{REFERENCES}

Ades, A. and R. Di Tella (1997): The New Economics of Corruption: A Survey and some New Results. Political Studies, 45: 496-515.

Ades, A. and R. Di Tella (1999): Rents, Competition, and Corruption, American Economic Review, 89(4): 982-993.

Bardhan, P. (1997): Corruption and Development: A Review of Issues. Journal of Economic Literature, 3: 1320-1346.

Berman, S. (1997): Civil Society and the Collapse of the Weimar Republic. World Politics, 49(3): 401-429.

Beugelsdijk, S. and S. Smulders (2003): "Bonding and Bridging Social Capital: Which Type is Good for Economic Growth?" in: W. Arts, L. Halman and J. Hagenaars (eds.) The Cultural Diversity of European Unity, Leiden: Brill, pp. 147-184.

Bjørnskov, C. (2003): Corruption and Social Capital. Working Paper, 03-13: Aarhus School of Business.

Bjørnskov, C. (2008): Social Trust and Fractionalization: A Possible Reinterpretation. European Sociological Review, 24(3): 271-283.

Blau, P.M. (1977): Inequality and Heterogeneity: A Primitive Theory of Social Structure. New York: Free Press.

Boix, C. and D. Posner (1998): Social Capital: Explaining its Origins and Effects on Government Performance. British Journal of Political Science, 28: 686-693.

Coffé, H. and B. Geys (2005): Institutional Performance and Social Capital: An Application to the Local Government Level, Journal of Urban Affairs, 27(5): 485-501.

Coffé, H. and B. Geys (2006): Community Heterogeneity: A Burden for the Creation of Social Capital? Social Science Quarterly, 87(5): 1053-1072.

Coffé, H. and B. Geys (2007): Towards an Empirical Characterization of 'Bridging' and 'Bonding' Social Capital. Non-Profit and Voluntary Sector Quarterly, 36(1): 121-139.

Coffé, H. and B. Geys (2008): Measuring the Bridging Potential of Voluntary Associations: The Importance of Association Size. Sociology, 42(2): 357-369.

Coleman, J.S. (1988): Social Capital in the Creation of Human Capital. American Journal of Sociology, 94: S95-S120.

Coleman, J.S. (1990): Foundations of Social Theory. Cambridge: Harvard University Press.

Cornwell, B. and J.A. Harrison (2004): Union Membership and Voluntary Associations: Membership Overlap as a Case of Organizational Embeddedness. American Sociological Review 69(6): 862-881.

Delhey, J. and K. Newton (2005): Predicting Cross-National Levels of Social Trust: Global Pattern or Nordic Exceptionalism? European Sociological Review, 21(4): 311-327.

Delhey, J., K. Newton and C. Welzel (2011). How General is Trust in "Most People"? Solving the Radius of Trust Problem. American Sociological Review, forthcoming.

Dreher, A. and M. Gassebner (2011): Greasing the Wheels of Entrepreneurship? The Impact of Regulations and Corruption on Firm. Public Choice, forthcoming.

Egger, P. and H. Winner (2005): Evidence on corruption as an incentive for foreign direct investment. European Journal of Political Economy, 21: 932- 952. 
ESS (2010). European Social Survey Round 5 Source Questionnaire. London: Centre for Comparative Social Surveys, City University London.

Fisman, R. and Gatti (2002): Decentralization and Corruption: Evidence across Countries. Journal of Public Economics 83: 325-345.

Foley, M.W. and B. Edwards (1998): Beyond Toqueville: Civil Society and Social Capital in Comparative Perspective. American Behavioral Scientist, 42(1), 5-20.

Freitag, M (2006): Bowling the State Back in: Political Institutions and the Creation of Social Capital. European Journal of Political Research, 45: 123-152.

Freitag, M., N. Grießhaber and R. Traunmüller (2009): Vereine als Schulen des Vertrauens? Eine empirische Analyse zur Zivilgesellschaft in der Schweiz. Swiss Political Science Review, 15(3): 463-495.

Fukuyama, F. (2000): Social Capital and Civil Society. IMF Working Paper, WP/00/74.

Gerring, J. and S.C. Thacker (2005): Do Neoliberal Policies Deter Political Corruption? International Organization 59(1): 233-254.

Geys, B. and Z. Murdoch (2008): How to make Head or Tail of Bridging and Bonding?: Addressing the Methodological Ambiguity. British Journal of Sociology, 59(3): 435-454.

Geys, B. and Z. Murdoch (2010): Measuring the 'Bridging' versus 'Bonding' Nature of Social Networks: A Proposal for Integrating Existing Measures. Sociology, 44(3), 523-540.

Grajzl, P. and P. Murrell (2009): Fostering Civil Society to Build Institutions. Economics of Transition, 17(1): 1-41.

Granovetter, M. (1973): The Strength of Weak Ties. American Journal of Sociology, 78(6): 1360-1380.

Grossman, G.N. and E. Helpman (2001): Special Interest Politics. Cambridge: MIT Press.

Harris, D. (2007): Bonding Social Capital and Corruption: A Cross-National Empirical Analysis. Environmental Economy and Policy Research Working Papers, No 27.2007: University of Cambridge.

Hooghe, M. and D. Stolle (2003): Introduction: Generating Social Capital. Pp. 1-18 in: M. Hooghe and D. Stolle (eds.), Generating Social Capital. Civil Society and Institutions in Comparative Perspective. Basingstoke: Palgrave Macmillan.

Iglič, H. (2010): Voluntary Associations and Tolerance: An Ambiguous Relationship. American Behavioral Scientist, 53(5): 717-736.

Jain, A.K. (2001): Corruption: A Review. Journal of Economic Surveys, 15(1): 69-121.

Jottier, D. and B. Heyndels (2011): Does Social Capital Increase Political Accountability? An Empirical Test for Flemish Municipalities, Public Choice, forthcoming.

Kaufmann, D., A. Kray and M. Mastruzzi (2003): Governance Matters III: Governance Indicators for 1996, 1998, 2000, and 2002. World Bank Economic Review, 18(2): 253-287.

Klitgaard, R.E. (1988): Controlling Corruption. Berkeley: University of California Press.

Knack, S. (2002): Social Capital and the Quality of Government: Evidence from the States. American Journal of Political Science, 46: 772-785.

Knack, S. and O. Azfar (2003): Trade Intensity, Country Size and Corruption. Economics of Governance, 4: 1-18. 
Knack, S. and P. Keefer (1997): Does Social Capital Have an Economic Payoff? A CrossCountry Investigation. Quarterly Journal of Economics, 112(4): 1251-1288.

Lambsdorff, J.G. (2003): Background Paper to the 2003 Corruption Perceptions Index. Transparency International and University of Passau.

Lambsdorff, J. G. (2007): The Institutional Economics of Corruption and Reform: Theory, Evidence and Policy. New York: Cambridge University Press.

La Porta, R., F. Lopez-de-Silanes, A. Shleifer and R. Vishny (1997): Trust in Large Organizations. American Economic Review (Papers and Proceedings), 87: 333-338.

La Porta, R., F. Lopez-de-Silanes, A. Shleifer and R. Vishny (1999): The Quality of Government. Journal of Law, Economics and Organization, 15(1): 222-279.

Leff, N. (1964): Economic Development Through Bureaucratic Corruption. American Behavioural Scientist, 8: 8-14.

Levi, M. (1996): Social and Unsocial Capital: A Review Essay of Robert Putnam's Making Democracy Work. Politics and Society, 24: 45-55.

Mauro, P. (1995): Corruption and Growth. Quarterly Journal of Economics 110(3): 681-712.

Méon, P.-G. and L. Weill (2010): Is Corruption an Efficient Grease? World Development, 38(3): 244-259.

Messner, S.F., E.P. Baumer and R. Rosenfeld (2004): Dimensions of Social Capital and Rates of Criminal Homicide. American Sociological Review, 69(6): 882-903.

Morris, S.D. and J.L. Klesner (2010): Corruption and Trust: Theoretical Considerations and Evidence from Mexico. Comparative Political Studies, 20(10): 1-28.

Narayan, D. (1999): Bonds and Bridges: Social Capital and Poverty. World Bank Research Working Papers.

Newton, K. (2006): Political Support: Social Capital, Civil Society and Political and Economic Performance. Political Studies, 54(4): 846-864.

O'Connell, M. (2003): Anti 'Social Capital'. Civic Values versus Economic Equality in the EU. European Sociological Review, 19(3): 241-248.

Olson, M. (1965): The Logic of Collective Action: Public Goods and the Theory of Groups. Cambridge: Cambridge University Press.

Olson, M. (1982): The Rise and Decline of Nations. New Haven: Yale University Press.

Paldam, M. (2002): The Cross-Country Pattern of Corruption: Economics, Culture and the Seesaw Dynamics. European Journal of Political Economy, 18: 215-240.

Paxton, P. (1999): Is Social Capital Declining in the United States? A Multiple Indicator Assessment. American Journal of Sociology 105: 88-127.

Paxton, P. (2002): Social Capital and Democracy: An Interdependent Relationship. American Sociological Review, 67(2): 254-277.

Paxton, P. (2007): Association Memberships and Generalized Trust: A Multilevel Model Across 31 Countries. Social Forces, 86(1): 47-76.

Pichler, F. and C. Wallace (2007): Patterns of Formal and Informal Social Capital in Europe. European Sociological Review, 23(4): 423-435.

Portes, A. (1998): Social Capital: Its Origins and Applications in Modern Sociology. Annual Review of Sociology, 22: 1-24. 
Putnam, R.D. (1993): Making Democracy Work. Civic Traditions in Modern Italy. Princeton: Princeton University Press.

Putnam, R.D. (2000): Bowling Alone. The Collapse and Revival of American Community. New York: Simon \& Schuster.

Rothstein, B. (2006): Social Traps and the Problem of Trust. Cambridge: Cambridge University Press.

Sabatini, F. (2009): Social Capital as Social Networks: A New Framework for Measurement and an Empirical Analysis of its Determinants and Consequences. Journal of SocioEconomics, 38: 429-442.

Scheufele, D.A., M.C. Nisbet, D. Brossard and E.C. Nisbet (2004): Social Structure and Citizenship: Examining the Impacts of Social Setting, Network Heterogeneity, and Informational Variables on Political Participation. Political Communication, 21(3): 315338.

Seldadyo, H. and J. de Haan (2006): The Determinants of Corruption. A Literature Survey and New Evidence. Paper presented at 2006 EPCS Conference, Turku, Finland: 20-23 April.

Shleifer, A. and R. Vishny (1993): Corruption. Quarterly Journal of Economics, 108(3): 599617.

Sønderskov, K.M. (2011): Does Generalized Social Trust Lead to Associational Membership? Unravelling a Bowl of Well-Tossed Spaghetti. European Sociological Review, 27(4): 419434.

Søreide, T. (2003): Estimating Corruption: Comments on Available Data. U4 Reports, Utstein Anti-Corruption Resource Centre.

Svensson, J. (2005): Eight Questions about Corruption. Journal of Economic Perspectives, 19(5): 19-42.

Tanzi, V. (1998): Corruption around the World. Causes, Consequences, Scope and Cures. IMF Staff Papers, 45(4): 559-594.

Tavits, M. (2006): Making Democracy Work More? Exploring the Linkage between Social Capital and Government Performance. Political Research Quarterly, 59(2): 211-225.

Treisman, D. (2000): The Causes of Corruption: A Cross-National Study. Journal of Public Economics, 76: 399-457.

Treisman, D. (2007): What Have We Learned About the Causes of Corruption From 10 Years of Cross-National Empirical Research? Annual Review of Political Science, 10: 211-244.

Uslaner, E.M. (2003): Varieties of Trust. European Political Science, 2(3): 43-49.

Uslaner, E.M. (2004): Trust and Corruption. Pp. 76-92 in: J.G. Lambsdorff, M. Taube and M. Schramm (Eds.), Corruption and the New Institutional Economics. London: Routledge.

van Deth, J.W. (2010): Participation in Voluntary Associations: Dark Shades in a Sunny World? American Behavioral Scientist, 53(5): 640-656.

van Deth, J.W. and S. Zmerli (2010): Introduction: Civicness, Equality, and Democracy - A "Dark Side" of Social Capital? American Behavioral Scientist, 53(5): 632-639.

Warren, M.E. (2001): Democracy and Associations. Princeton: Princeton University Press.

Warren, M.E. (2004): Social Capital and Corruption. Democracy and Society, 1(Spring): 1, 16-18. 
You, J.S (2006): A Comparative Study of Corruption, Inequality, and Social Trust. Unpublished doctoral dissertation, Massachusetts: Harvard University.

You, J.S. and S. Khagram (2005): A Comparative Study of Inequality and Corruption." American Sociological Review 70(1): 136-157.

Zmerli, S. (2003): Applying the Concepts of Bonding and Bridging Social Capital to Empirical Research. European Political Science, 2(3): 68-75.

Zmerli, S. (2010): Social Capital and Norms of Citizenship: An Ambiguous Relationship? American Behavioral Scientist, 53(5): 657-676. 


\section{APPENDIX A}

Table A1 Summary statistics of metric variables

\begin{tabular}{|c|c|c|c|c|c|c|c|}
\hline Variable & Obs. & Mean & Std. Dev. & Min & Max & Source & Description \\
\hline CPI 2003 & 20 & 7.285 & 1.78 & 3.6 & 9.7 & $\begin{array}{l}\text { Transparancy } \\
\text { International }\end{array}$ & $\begin{array}{l}\text { Continuous index on scale from } 0 \\
\text { (highly corrupt) to } 10 \text { (highly clean) }\end{array}$ \\
\hline Active Involvement & 20 & 37.65 & 13.80 & 12.66 & 53.25 & $\begin{array}{l}\text { ESS, own } \\
\text { calculations }\end{array}$ & $\begin{array}{l}\text { Percentage of respondents active in at } \\
\text { least one association type }\end{array}$ \\
\hline Active in Exclusive Associations & 20 & 14.21 & 6.31 & 4.42 & 25.03 & $\begin{array}{l}\text { ESS, own } \\
\text { calculations }\end{array}$ & $\begin{array}{l}\text { Percentage of respondents active in at } \\
\text { least one exclusive association }\end{array}$ \\
\hline Active in Inclusive Associations & 20 & 30.83 & 12.43 & 9.28 & 45.70 & $\begin{array}{l}\text { ESS, own } \\
\text { calculations }\end{array}$ & $\begin{array}{l}\text { Percentage of respondents active in at } \\
\text { least one inclusive association }\end{array}$ \\
\hline Active in Isolated Associations & 20 & 13.61 & 5.88 & 4.66 & 25.54 & $\begin{array}{l}\text { ESS, own } \\
\text { calculations }\end{array}$ & $\begin{array}{l}\text { Percentage of respondents active in at } \\
\text { least one isolated association }\end{array}$ \\
\hline Active in Connected Associations & 20 & 30.42 & 12.66 & 8.98 & 48.34 & $\begin{array}{l}\text { ESS, own } \\
\text { calculations }\end{array}$ & $\begin{array}{l}\text { Percentage of respondents active in at } \\
\text { least one connected association }\end{array}$ \\
\hline GDP per capita 2000 & 20 & $25,447.15$ & $9,029.123$ & 10,555 & 53,315 & OECD Factbook & In US-Dollars, \\
\hline Generalized Trust & 20 & 5.01 & 0.97 & 3.64 & 6.99 & $\begin{array}{l}\text { ESS, own } \\
\text { calculations }\end{array}$ & $\begin{array}{l}\text { Average trust of respondents between } \\
0 \text { (you cannot be too careful) and } 10 \\
\text { (most people can be trusted) }\end{array}$ \\
\hline
\end{tabular}
data. 
Table A2: Isolated and connected associations (based on average number of memberships)

\begin{tabular}{|c|c|c|c|c|c|c|c|c|c|c|}
\hline Organization & AT & BE & DE & DK & ES & FI & FR & GB & GR & HU \\
\hline Sport/Outdoor Activity & $2.7(0.002)$ & $2.3(-0.008)$ & $2.1(-0.003)$ & $2.0(0.124)$ & $2.2(0.029)$ & $1.8(-0.048)$ & $2.1(0.057)$ & $2.2(0.174)$ & $2.0(0.035)$ & $2.3(0.165)$ \\
\hline Cultural/Hobby Club & $2.9(0.252)$ & $2.8(0.154)$ & $2.5(0.139)$ & $2.4(0.141)$ & $2.6(0.311)$ & $2.1(0.084)$ & $2.3(0.191)$ & $2.6(0.200)$ & $2.1(0.280)$ & $2.4(0.390)$ \\
\hline Trade Union & $3.4(-0.179)^{\mathrm{i}}$ & $3.4(-0.434)^{\mathrm{i}}$ & $2.4(-0.343)^{\mathrm{i}}$ & $2.4(-0.224)^{\mathrm{i}}$ & $2.6(-0.054)$ & $2.1(-0.254)^{\mathrm{i}}$ & $3.0(-0.010)$ & $3.4(0.130)$ & $2.0(-0.053)$ & $2.1(-0.938)^{\mathrm{i}}$ \\
\hline Bus./Prof./ Farmers Org. & $3.9(0.359)$ & $3.4(-0.374)^{\mathrm{i}}$ & $2.7(-0.135)^{\mathrm{i}}$ & $3.1(0.142)$ & $2.7(0.029)$ & $2.4(0.029)$ & $2.8(-0.319)^{\mathrm{i}}$ & $3.2(0.086)$ & $1.9(-0.210)^{\mathrm{i}}$ & $2.8(-0.153)$ \\
\hline Consumer/Automobile Org. & $3.7(0.117)$ & $4.8(0.662)$ & $2.9(-0.002)$ & $3.5(0.296)$ & $2.4(-0.282)^{\mathrm{i}}$ & $2.2(-0.240)^{\mathrm{i}}$ & $3.8(0.674)$ & $3.1(-0.172)^{\mathrm{i}}$ & $2.9(0.332)$ & $4.6(1.031)$ \\
\hline Humanitarian Aid/Human Rights/Minorities & $3.6(0.200)$ & $3.8(-0.020)$ & $2.9(0.093)$ & $2.9(-0.092)$ & $2.6(0.085)$ & $2.4(0.052)$ & $2.9(-0.003)$ & $3.2(0.029)$ & $3.2(0.703)$ & $3.5(0.022)$ \\
\hline Environment/Peace/Animal Rights & $3.1(-0.258)^{\mathrm{i}}$ & $3.8(-0.017)$ & $2.9(0.174)$ & $2.9(-0.194)$ & $2.7(0.067)$ & $2.7(0.275)$ & $3.2(0.227)$ & $3.2(0.003)$ & $2.6(0.146)$ & $3.5(0.022)$ \\
\hline Church/Religious Org. & $2.9(-0.134)$ & $3.5(-0.261)^{\mathrm{i}}$ & $2.5(-0.100)$ & $2.5(-0.331)^{\mathrm{i}}$ & $2.0(-0.457)^{\mathrm{i}}$ & $2.0(-0.116)^{\mathrm{i}}$ & $2.2(-0.668)^{\mathrm{i}}$ & $2.4(-0.229)^{\mathrm{i}}$ & $1.2(-1.233)^{\mathrm{i}}$ & $2.2(-0.193)^{\mathrm{i}}$ \\
\hline Political Party & $3.4(-0.038)$ & $4.2(0.297)$ & $3.0(0.228)$ & $3.3(0.215)$ & $3.2(0.527)$ & $2.5(0.061)$ & $3.3(0.187)$ & $3.6(0.231)$ & $2.1(0.032)$ & $3.0(-0.370)^{\mathrm{i}}$ \\
\hline Science/Education/Teachers/Parents & $3.3(-0.072)$ & $3.5(-0.086)$ & $2.8(0.104)$ & $3.2(0.153)$ & $2.5(-0.009)$ & $2.4(0.121)$ & $2.7(-0.199)^{\mathrm{i}}$ & $2.7(-0.170)$ & $2.3(0.104)$ & $2.9(-0.052)$ \\
\hline Social Club, Young/Elderly/Women & $3.0(-0.250)^{\mathrm{i}}$ & $2.9(0.087)$ & $2.3(-0.155)^{\mathrm{i}}$ & $2.5(-0.230)^{\mathrm{i}}$ & $2.1(-0.246)^{\mathrm{i}}$ & $2.3(0.036)$ & $2.5(-0.137)$ & $2.3(-0.281)^{\mathrm{i}}$ & $2.0(-0.137)^{\mathrm{i}}$ & $2.6(0.076)$ \\
\hline Organization & IE & IL & IT & LU & NL & NO & PL & PT & SE & SI \\
\hline Sport/Outdoor Activity & $2.4(0.142)$ & $2.3(0.093)$ & $2.0(0.045)$ & $1.8(0.117)$ & $2.0(0.116)$ & $2.3(0.001)$ & $1.9(0.015)$ & $2.2(0.147)$ & $2.1(0.060)$ & $1.7(0.033)$ \\
\hline Cultural/Hobby Club & $3.0(0.105)$ & $2.3(0.221)$ & $2.6(0.349)$ & $2.2(0.384)$ & $2.6(0.002)$ & $2.8(0.093)$ & $2.1(0.303)$ & $3.0(0.404)$ & $2.6(0.139)$ & $2.2(0.187)$ \\
\hline Trade Union & $3.1(-0.288)^{\mathrm{i}}$ & $3.5(0.503)$ & $2.0(-0.405)^{\mathrm{i}}$ & $2.4(-0.370)^{\mathrm{i}}$ & $3.2(0.036)$ & $3.0(-0.099)$ & $1.6(-0.528)^{\mathrm{i}}$ & $2.5(-0.566)^{\mathrm{i}}$ & $2.7(-0.241)^{\mathrm{i}}$ & $1.7(-0.461)^{\mathrm{i}}$ \\
\hline Bus./Prof./ Farmers Org. & $3.0(-0.207)$ & $4.2(1.003)$ & $2.7(0.098)$ & $2.6(-0.226)$ & $3.0(0.010)$ & $3.6(0.326)$ & $2.2(0.008)$ & $2.9(-0.177)$ & $3.2(0.170)$ & $2.1(-0.009)$ \\
\hline Consumer/Automobile Org. & $3.9(0.300)$ & $3.3(0.136)$ & $3.0(0.145)$ & $4.6(1.481)$ & $3.3(0.166)$ & $3.2(-0.244)^{\mathrm{i}}$ & $2.1(-0.196)^{\mathrm{i}}$ & $3.6(0.358)$ & $3.1(-0.025)$ & $2.5(0.258)$ \\
\hline Humanitarian Aid/Human Rights/Minorities & $3.7(0.269)$ & $2.8(-0.190)$ & $2.6(-0.006)$ & $2.5(-0.324)$ & $3.1(0.014)$ & $3.4(0.065)$ & $2.2(-0.035)$ & $3.1(0.235)$ & $2.8(-0.194)^{\mathrm{i}}$ & $1.9(-0.305)^{\mathrm{i}}$ \\
\hline Environment/Peace/Animal Rights & $3.6(0.175)$ & $2.7(-0.282)^{\mathrm{i}}$ & $2.9(0.192)$ & $2.9(-0.014)$ & $2.9(-0.233)^{\mathrm{i}}$ & $3.5(0.004)$ & $2.6(0.337)$ & $3.2(0.143)$ & $3.2(0.069)$ & $2.5(0.179)$ \\
\hline Church/Religious Org. & $2.5(-0.217)^{\mathrm{i}}$ & $2.3(-0.761)^{\mathrm{i}}$ & $2.2(-0.318)^{\mathrm{i}}$ & $2.6(-0.359)^{\mathrm{i}}$ & $2.5(-0.210)^{\mathrm{i}}$ & $2.8(-0.345)^{\mathrm{i}}$ & $1.5(-0.391)^{\mathrm{i}}$ & $1.8(-0.310)^{\mathrm{i}}$ & $2.6(-0.300)^{\mathrm{i}}$ & $2.1(-0.100)^{\mathrm{i}}$ \\
\hline Political Party & $3.3(-0.299)^{\mathrm{i}}$ & $2.7(-0.373)^{\mathrm{i}}$ & $2.7(-0.001)$ & $2.8(-0.155)$ & $3.5(0.296)$ & $3.4(0.073)$ & $2.3(0.017)$ & $2.9(-0.102)$ & $3.5(0.482)$ & $2.3(0.112)$ \\
\hline Science/Education/Teachers/Parents & $3.4(0.087)$ & $2.6(-0.171)$ & $2.8(-0.031)$ & $2.7(-0.201)$ & $2.9(-0.044)$ & $3.5(0.244)$ & $2.3(0.203)$ & $3.0(0.088)$ & $2.9(0.009)$ & $2.3(0.053)$ \\
\hline Social Club, Young/Elderly/Women & $2.9(-0.067)$ & $2.3(-0.179)$ & $2.6(-0.069)^{\mathrm{i}}$ & $2.1(-0.333)^{\mathrm{i}}$ & $2.8(-0.152)^{\mathrm{i}}$ & $2.7(-0.117)^{\mathrm{i}}$ & $2.4(0.266)$ & $2.6(-0.220)^{\mathrm{i}}$ & $2.5(-0.168)$ & $2.0(0.051)$ \\
\hline
\end{tabular}

Average number of memberships among the members of a specific association type reported; Size corrected figures in brackets; $i=$ isolated association type 